\title{
GENDER QUOTAS FOR CORPORATE BOARDS: OPTIONS FOR LEGAL DESIGN IN THE UNITED STATES
}

\author{
Anne L. Alstott ${ }^{*}$
}

The gender gap in U.S. business leadership remains shockingly wide. Today, $57.6 \%$ of all bachelors' and higher degrees are awarded to women, including $54.2 \%$ of social science and law degrees, and $43.5 \%$ of science and mathematics degrees. ${ }^{1}$ But, despite their academic prowess, women find their careers stalled before they reach top management. In 2012, women held $16.6 \%$ of seats on Fortune 500 boards. One-tenth of the Fortune 500 had no women at all on their boards. ${ }^{2}$

Thanks to social science research, we know that the attitudes and social structures that produce the gender gap are deeply embedded in our institutions and our psyches. ${ }^{3}$ And yet,

\footnotetext{
* Jacquin D. Bierman Professor in Taxation, Yale Law School. Arthur Ewenczyk provided outstanding research assistance.

${ }^{1}$ Digest of Education Statistics: Table 425 Percentage of bachelor's and higher level degrees awarded to women, by field of study and country, NCES.ED.GOV (July 2011), http:/nces.ed.gov/programs/ digest/d11/tables/dt11_425.asp. (U.S. women earn $43.5 \%$ of math and science degrees overall but a lower percentage in computer science (20.8\%) and engineering $(21.4 \%)$ ).

${ }^{2}$ Rachel Soares, 2012 Catalyst Census: Fortune 500 Women Board Directors, CATALYST (Dec. 11, 2012), http://www.catalyst.org/knowledge/2012catalyst-census-fortune-500-women-board-directors.

${ }^{3}$ See, e.g., Corinne Moss-Racusin, et al., Science Faculty's Subtle Gender Biases Favor Male Students, 109 J. OF THE AM. CHEM. SOC'Y 41 16474-79 (2013), available at http://www.pnas.org/content/109/41/16474.full (finding that male and female science faculty reviewing identical student applications favored those with male names); Priyanka B. Carr \& Claude Steele, Stereotype Threat and Inflexible Perseverance in Problem Solving, 45 J. OF EXPERM. PSYCH. 853 (2009), available at https://psychology.stanford.edu/ sites/all/files/JESP article inpress.pdf (examining how stereotype threat, the threat of confirming a negative stereotype about one's group, depresses women's performance in a testing situation); Virginia Valian, Beyond Gender Schema: Improving the Advancement of Women in Academia, 20 Hypatia
} 
traditional anti-discrimination law is not well-suited to detect or redress implicit bias and other subtle dynamics of discrimination. ${ }^{4}$

Recently, U.S. activists, scholars, and policy makers have turned their attention to one notable effort to address the gender gap in management: gender quotas for corporate boards of directors. Twelve European countries have pioneered quotas in this context. France, Italy, the Netherlands, Norway, and Belgium now have mandatory quotas ranging from 30\%-40\%. Spain, Germany, Denmark, Finland, Greece, Austria, and Slovenia have voluntary quotas, and Germany and the EU are considering legislation to mandate quotas. ${ }^{5}$

Gender quotas for corporate boards represent an intriguing option, even if the case for quotas is not airtight. The argument for gender quotas rests on a number of empirical propositions, all of which remain contested. Scholars cannot yet show definitively whether gender quotas shatter the glass ceiling or improve board decisionmaking or business performance. Indeed, critics worry that quotas could produce a backlash, if female appointees are tokens or if female directors are untrained or inexperienced, but these claims, too, await further empirical investigation.

What is certain, however, is that gender quotas represent the kind of structural change that could alter business practices that exclude women from leadership roles. Social psychology has demonstrated that gender discrimination flourishes when institutions allow actors to give free reign to stereotypes and to unconscious biases. ${ }^{6}$ We now know that, to be effective, anti-discrimination measures must aim to alter business prac-

(2005), available at http://maxweber.hunter.cuny.edu/psych/faculty /valian/docs/2005BeyoundGender.pdf (examining gender schemas and the accumulation of advantage).

${ }^{4}$ See Jerry Kang \& Mahzarin Banaji, Fair Measures: A Behavioral Realist Revision of 'Affirmative Action', 94 CALIF. L. REV. 1063 (2006).

5 Women in economic decision-making in the EU: Progress report, EuR. COMM'N: JUSTICE (2012), http://ec.europa.eu/justice/genderequality/files/women-on-boards_en.pdf [hereinafter Women in DecisionMaking]; see also WOMEN ON BOARDS, GOv.UK, https://www.gov.uk/government/uploads/system/uploads/attachment_data/file /31480/11-745-women-on-boards.pdf (recommending that UK firms set targets for female board members and that UK rules should encourage disclosure of board composition).

${ }^{6}$ See Kang, supra note 4. 
tices to inform actors about these biases and to limit the effects of bias on hiring, promotion, and the distribution of rewards in the workplace and in society. ${ }^{7}$

Still, gender quotas may seem a cultural and legal oddity in the United States; a European transplant unlikely to take root here. Whether gender quotas violate the U.S. Constitution's Equal Protection Clause, for instance, is a serious issue. ${ }^{8}$ But even if a quota could survive constitutional scrutiny, gender quotas for corporate boards seem to represent the kind of intrusive state regulation of business that our nation's laissez faire ideology seems to reject. ${ }^{9}$ The United States is inhospitable to central planning and industrial policy, and its weak union infrastructure and hands-off corporate governance tradition would seem to offer no launching pad for gender quotas. American ideals of free markets, investor choice, and employment at will sit uneasily, to put it mildly, with the notion that the state should dictate to investors the gender of the decisionmakers entrusted with the management of their money.

But a closer look at U.S. institutions reveals that the cultural and legal mismatch is not as severe as it may first appear. In this paper, I suggest that gender quotas, if designed with sensitivity to exceptional U.S. institutions, could fit comfortably with U.S. law. To illustrate, I offer two examples: the role of taxation in U.S. business regulation, and the role of nonprofits in the economy.

Begin with the surprising degree to which the United States regulates business via the tax law. Despite many public statements (and academic studies) pronouncing the United States a laissez faire economy, the United States actually engages in heavy-handed and expensive regulation of business for social ends. ${ }^{10}$ But for political and ideological reasons, the

${ }^{7} \mathrm{Id}$.

8 See, e.g., Regents of the Univ. of California v. Bakke, 438 U.S. 265 (1978) (ruling that the use of racial quotas in the admission process of a public university was unconstitutional); Mississippi Univ. for Women v. Hogan, 458 U.S. 718 (1982) (striking down the women-only admissions policy of a state nursing school).

9 On law and neoliberalism, see David Singh Grewal and Jedediah S. Purdy, Introduction: Law and Neoliberalism, J. L. \& CONTEMP. PROBS. (forthcoming 2014), available at http://papers.ssrn.com/ sol3/papers.cfm?abstract_id=2341068.

10 See text accompanying notes 23-38. 
United States builds its industrial policy into the federal income tax law. In other countries, the tax law is a relatively dry field, concerned mostly with revenue-raising. In the United States, by contrast, the state makes massive expenditures to further social and economic policy under the guise of "tax incentives." 11

Once we understand how U.S. law structures its national industrial policy, we can begin to see how gender quotas might mesh with existing legal institutions. This article sketches how tax incentives and penalties, combined with securities disclosure rules, might constitute a quota regime-or backstop a regime enacted via anti-discrimination law. Tax and securities laws have several advantages over other options: they draw upon expertise that already exists in the corporate sector and the government, and they could foster publicity and public accountability.

A second design issue for the United States concerns the application of gender quotas to the nonprofit sector. The U.S. nonprofit sector is notably large, influential, and wellintegrated with business and government. Nonprofits include a huge portion of firms in the health care sector, as well as the vast majority of private educational institutions. Including some of the larger nonprofits in a gender quota could open pathways to leadership for women in academia and medicine as well as business. While tax incentives and securities disclosure rules would not automatically apply to nonprofits, careful design could extend the benefits of tax incentives to that sector as well.

\section{Gender Quotas AND U.S. Business REgulation}

Gender quotas have been justified on several grounds. First, and to my mind most persuasive, is the antidiscrimination rationale. ${ }^{12}$ On this view, quotas attempt to alter business structures to pave the way for the integration of women into business leadership. If mandated, quotas would not only create positions for female leaders but would also render salient the issue of gender in business leadership and could help nudge businesses to construct pathways for the develop-

\footnotetext{
${ }^{11}$ See text accompanying notes 23-36.

12 See, e.g., Women on Boards, supra note 5 at 17-18.
} 
ment of female leaders. ${ }^{13}$

A second rationale for gender quotas has also become prominent in the public sphere: the claim is that quotas can improve business performance. For instance, an EU "Progress Report" on the situation of women in business noted that studies find that companies with a greater share of "women at top levels deliver strong organisational (sic) and financial performance." 14

The empirical basis for the higher earnings claim is aggregate data showing that companies with higher percentages of female directors earned more, all else equal. ${ }^{15}$ Researchers posit several pathways to better corporate performance. Female board members may better understand the experiences and needs of female workers and customers, for example. ${ }^{16}$ Greater diversity among board members may combat the tendency toward groupthink. ${ }^{17}$ And female board members may have distinctive preferences, exhibiting a longer-term perspective, greater reluctance to lay off workers, and greater attention to monitoring duties. ${ }^{18}$

${ }^{13}$ For evidence, see, e.g., Beate Elstad \& Gro Ladegard, Women on Corporate Boards: Key Influencers or Tokens?, J. OF MGMT. \& GOVERNANCE (2010), available at http://papers.ssrn.com/sol3/papers. cfm?abstract_id=1582368 (finding that greater percentages of women on boards correlate with women's perceived influence).

14 Women in Decision-Making, supra note 5 , at 8.

15 See, e.g., Kevin Campbell \& Antonio Minguez-Vera, Gender Diversity in the Boardroom and Firm Financial Performance, 83 J. Bus. ETHICs 435 (2008) (finding that greater gender diversity on boards increased firm values). Cf. Vic Murray, Pat Bradshaw \& Jacob Wolpin, Women on Boards of Nonprofits: What Difference Do They Make?, 6 NonPRofit MGMT. \& LEADERSHIP 241 (1996) (studying nonprofits in Canada and finding no effects of gender diversity on board effectiveness but positive effects on subjective satisfaction with the board's performance).

16 The organization 2020 Women on Boards highlights the representativeness claim on its website, noting that women have "different backgrounds, experiences, and perspectives" and implying that female directors can better represent female workers and customers. Why Gender Diversity Matters, 2020WOB.COM (2011), available at http://www.2020wob.com/learn/why-gender-diversity-matters; see also Women Decision Making, supra note 5, at 7 (arguing that " $[\mathrm{m}]$ lore women in management can...provide a broader insight in economic behavior and consumers' choices").

17 See Women in Decision-Making, supra note 5, at 7 (arguing that a "diverse board of directors contributes to better performance because decisions are based on evaluating more alternatives compared to homogenous boards").

18 See David A. Matsa \& Amalia R. Miller, A Female Style in Corporate 
Still, the claim that gender quotas improve corporate performance is less robust than some advocates admit. Some studies prove only that companies that voluntarily hire female directors perform well. It does not follow that companies forced to hire female directors would reap any benefits at all: indeed, a strong market-efficiency advocate would suppose that existing companies have optimized their mix of directors: those companies that have female directors are those that benefit from their presence, while those that do not have concluded that hiring women would reduce performance.

Indeed, some studies show that mandatory gender quotas lower share prices or earnings. ${ }^{19}$ Kenneth Ahern and Amy Dittmar, for instance, found that Norway's gender quota resulted in immediate and lasting declines in stock prices. They infer that prior board selection had been made to maximize value. Ahern and Dittmar also found that the board quotas resulted in younger and less experienced boards. ${ }^{20}$

The mixed evidence does not, of course, put the matter to rest. One might argue, for example, that female directors' greater reluctance to lay off workers reflects a praiseworthy social orientation, even if profits and share prices fall. Another argument is that gender quotas may have short-term costs due to new female directors' inevitable inexperience (due to discrimination) but will produce long-term gains, despite the stock market's skepticism reflected in the price drop found by Ahern

Leadership? Evidence from Quotas, AM. ECON. J (2012), available at http:/papers.ssrn.com/sol3/papers.cfm?abstract_id=1636047) (comparing firms affected and unaffected by Norway's 2006 gender quota, the authors find that firms affected by the mandate made fewer layoffs, increasing labor costs and reducing short-term profits); see also Renee B. Adams \& Daniel Ferreira, Women in the Boardroom and Their Impact on Governance and Performance (2008), available at http://papers.ssrn.com/sol3/papers.cfm?abstract_id=1107721 (finding that female directors have better attendance records and join monitoring committees more readily; also finding that $\mathrm{CEO}$ compensation is more sensitive to stock performance when board have more gender diversity).

19 See, e.g., Adams \& Ferreira, supra note 15; Matsa \& Miller, supra note 15 (finding that firms affected by Norway's mandate had lower short-term profits).

20 See Kenneth R. Ahern \& Amy K. Dittmar, The Changing of the Boards: The Impact on Firm Valuation of Mandated Female Board Representation, 127 Q. J. Econ. 137 (2012), available at http:/papers.ssrn.com/sol3 /papers.cfm?abstract_id=1364470. 
and Dittmar. But the first claim is a normative proposition, and the second represents empirical speculation. The outcome of the argument awaits a fuller account of how corporations ought to make decisions on matters including layoffs and whether quotas improve performance in the long run.

While we wait for resolution of the unknown, we should take notice of a persistent objection: even if the higher earnings claim were empirically proved, gender quotas would still seem to fit uneasily with the laissez faire culture of business regulation in the United States.

U.S. law typically looks to the invisible hand of the marketplace to regulate business; the oft-repeated assertion is that the market is far better than the government at structuring business. Thus, a U.S.-trained legal economist might suppose that mandating gender quotas is unnecessary: firms that would benefit from greater female representation on boards would already have done so. Firms with lower gender ratios, conversely, must be those firms whose value is maximized without gender diversity. ${ }^{21}$

By this stage in the debate, the deeper problem with gender quotas is evident: quotas sit uneasily with deeply-held beliefs (in the United States) about the role of government and law in regulating business. The United States (seemingly) tolerates little government regulation of business. Union representation has reached the vanishing point, and we lack the corporatist institutions that, in other countries, require capital owners regularly to come to the bargaining table to listen to the interests of other stakeholders.

State corporate law strongly illustrates the laissez faire cast of U.S. business law. The United States leaves to the states the primary responsibility for regulating corporate governance, initiating a well-known interstate competition for corporate charters. ${ }^{22}$ States by and large have settled on corporate laws that permit wide latitude to investors and managers in structuring corporate rules: the model is "enabling rather

21 This argument is distinct from the claim that markets will drive out discrimination: this argument essentially says that investors will optimize discrimination levels (which could be positive or zero) so as to maximize profits.

${ }^{22}$ See generally Roberto Romano, The State Competition Debate in Corporate Law, 8 CARDOZO L. REV. 709 (1987). 
than directory" in the service of economic efficiency. ${ }^{23}$ It is far more efficient, advocates say, to rely on investors to police their own interests than to suppose that the government can do better. ${ }^{24}$

The United States does impose federal securities regulation, but the regime does not aim to regulate the terms of securities; it aims only to mandate disclosure of material facts to investors. ${ }^{25}$ Even so, many large firms and large transactions are exempt, and even this degree of regulation has been controversial, with some legal scholars arguing that mandatory federal disclosure rules should be replaced either by market discipline or by competition among jurisdictions offering different securities law regimes. ${ }^{26}$

For many legal readers, Exhibit A in the U.S. laissez faire system might be the recent Supreme Court decision in Citizens United, which equated corporate spending with individual free expression. ${ }^{27}$ Corporations in the United States, it seems, have an inalienable right not only to hire and fire, but to spend their money as they choose, despite Congressional concern about the impact of corporate spending on the political process.

But despite the deep roots of laissez-faire thinking in U.S. business and academic circles, the law on the ground has a rather different cast. In fact, the United States regulates business pervasively-but distinctively - via tax penalties and subsidies and securities disclosure rules.

Begin with tax incentives and penalties, which are used in the United States more extensively than in Europe. Tax rules have key political advantages in the United States. They preserve the appearance of voluntarism (no company is forced to act in certain ways; they simply must pay higher taxes if they

${ }^{23}$ Frank H. Easterbrook, The Race for the Bottom in Corporate Governance, 95 VA. L. REV. 685, 688 (2009) ("Corporate law came to be enabling rather than directory in the United States because that serves investors' interest. . . . States that adopt inefficient regulation propel capital out of their jurisdictions").

${ }^{24} I d$.

25 Thomas L. Hazen \& David L. Ratner, Securities Regulation in a NUTSHELl 38 (2006).

26 Roberta Romano, The Need for Competition in International Securities Regulation (Nt'1 Bureau of Econ. Research, Working Paper No. 00-49, 2001), available $a t$ http://papers.ssrn.com/sol3/papers.cfm?abstract_id=278728.

${ }^{27}$ Citizens United v. Fed. Election Comm'n, 558 U.S. 310 (2010) (holding unconstitutional a federal law restricting corporate political spending). 
choose one business plan over another). Regulation via tax also has the signal advantage of appearing to cut taxes for business. But, in fact, the tax system spends trillions of dollars of government money to shape business decisions and craft what amounts to an industrial policy for the United States.

This tax-based industrial policy is hidden from the ordinary citizen and even the ordinary non-specialist lawyer, behind the veil of technicalities of the tax law. However, scholars have long noted U.S. exceptionalism in the use of tax law for social-welfare tasks (like subsidizing health care) and business subsidies. ${ }^{28}$ Moreover, the business sector is in on the secret: firms, especially large ones, typically pay considerable attention to tax planning, and the dollars at stake are large. Table 1 shows that tax expenditures are roughly $150 \%$ the size of the defense budget and $160 \%$ the size of domestic discretionary spending.

Table 1. U.S. Budget Comparisons, FY $2011^{29}$

\begin{tabular}{|l|l|}
\hline Tax expenditures & $\$ 1.08$ trillion \\
\hline Domestic discretionary spending & $\$ 671$ billion \\
\hline Defense spending & $\$ 744$ billion \\
\hline $\begin{array}{l}\text { Income tax revenue (individual }+ \text { cor- } \\
\text { porate) }\end{array}$ & $\$ 1.4$ trillion \\
\hline
\end{tabular}

Consider just a few examples. In fiscal years 2011-15, the federal government will spend hundreds of billions of dollars to

28 See e.g., Stanley Surrey, Pathways to Tax Reform (1973); Jacob Hacker, The Divided Welfare State: 'The Battle Over Public and Private Social Benefits in the United States (2002); Christopher Howard, The Hidden Welfare State: Tax Expenditures and Social Policy in the United States (1999); Christopher Howard, The Welfare State Nobody Knows: Debunking Myths About U.S. Social Policy (2008).

${ }^{29}$ Lily Batchelder \& Eric Toder, Government Spending Undercover, Spending Programs Administered by the IRS, CTR. FOR AMER. PROGRESS (Apr. 2010)

http://www.urban.org/UploadedPDF/1001365_undercover_spending.pdf. 
subsidize multinational corporations, ${ }^{30}$ the housing industry, ${ }^{31}$ the oil industry, ${ }^{32}$ and the stock market. ${ }^{33}$ Some tax expenditures have an explicit social purpose. For example, the federal government deliberately underwrites alternative fuels, solar power, other clean energy, and electric cars. ${ }^{34}$ Favored activities that prosper with tax dollars also include low-income housing, credit unions, and life insurance. ${ }^{35}$ In addition, enormous subsidies funnel hundreds of billions of dollars every year to the health insurance and pension sectors. ${ }^{36}$

The tax law also engages in substantive corporate governance regulation by penalizing corporate decisions deemed socially harmful. One provision, enacted when corporate CEO salaries skyrocketed in the 1980 s and early 1990 s, limits deductible compensation for top executives to $\$ 1$ million unless certain good-governance procedures are followed. These provisions include linking pay to performance and requiring approval by outside directors and shareholders. ${ }^{37}$ Congress lowered that limit to $\$ 500,000$ in 2008 for companies receiving TARP relief. ${ }^{38}$ These tax rules have been widely criticized. Critics worry that boards rubber-stamp executive compensation and that stock options and other incentive compensation create new management pathologies as executives seek to manage stock prices to improve their own pay. ${ }^{39}$ Still, for present purposes

30 The JCT estimates that the deferral of U.S. tax on foreign income costs $\$ 87$ billion over those five years; see JOINT COMM. ON TAXATION, 112TH CONG., Estimates of Federal TAX Expenditures For Fiscal Years 2011-2015 32 (Comm. Print 2012).

${ }^{31} I d$. at 36 (the JCT estimates that the home mortgage interest deduction, the deduction for property taxes, and the exclusion of capital gains on home sales will cost $\$ 704.4$ billion over the five-year period. Economists believe that much of the value of these provisions is captured by the real estate industry, including brokers, mortgage lenders, and home builders).

${ }^{32} \mathrm{Id}$. at 37 (according to the $\mathrm{JCT}$, just one tax benefit for the oil industry, the deduction for income attributable to domestic production, will cost $\$ 72.1$ billion over the five-year period).

${ }^{33} I d$. at 37 (reduced tax rates for capital gains and dividends benefit the stock market and companies that issue stock; they also benefit real estate. The tax expenditure for $2011-2015$ is $\$ 456.6$ billion).

34 Id. at $33-34$.

35 Id at 36,38

${ }^{36} \mathrm{Id}$. at $40-42$.

37 I.R.C. $\$ 162(\mathrm{~m})(2011)$

38 See I.R.C. $\$ 162(\mathrm{~m})(5)(2011)$.

${ }^{39}$ See e.g., Simon C.Y. Wong, Uses and Limits of Conventional Corporate Governance Instruments: Analysis and Guidance for Reform-Part 1, Private 
the point is not that Internal Revenue Code (IRC) section $162(\mathrm{~m})$ is exemplary policy; rather, the point is just that Congress has used the tax law to regulate corporate executive pay.

The tax law also regulates business practices in other ways. The law penalizes illegal bribes, kickbacks, and expenditures on lobbying, for instance, adding a tax penalty on top of legal penalties for ordinary fines and antitrust treble damages. ${ }^{40}$

Some of the most extensive and explicit business regulation in the tax code applies to nonprofit organizations. IRC Section 501(c) grants an income tax exemption to a wide variety of entities in the health-care, education, religious, and philanthropic sectors. ${ }^{41}$ In return for tax exemption, these entities must comply with a host of substantive governance rules. Charities, for example, may not engage in political campaigning, nonprofit hospitals must provide charity care to the indigent, and universities (along with other charities) may not earn more than a de minimis amount of income from commercial activities unrelated to their exempt purpose. ${ }^{42}$

In recent years, securities regulation has taken on a more activist coloration as well. Controversially, the Sarbanes-Oxley Act of 2002 engages in substantive corporate governance, including measures governing board responsibilities and increased management accountability for financial disclosures. ${ }^{43}$ In 2010, the SEC issued rules requiring firms to disclose board members' qualifications and (as discussed later in this paper) to disclose board diversity policies as well. ${ }^{44}$

Sector Opinion 14, INT'L FIN. CORP. (June 30, 2009) available at http:/www.ifc.org/wps/wem/connect/216bbc0048a7e724aa37ef6060ad5911/GC GF+PSO+issue+14+6-30-09+screen.pdf?MOD=AJPERES (noting that board approval and incentive compensation do not heavily constrain management); Cristopher D. Jones, The Million-Dollar Question: Has Congress Missed the Mark with I.R.C. $§ 162(m)$ Compensation Deduction Caps? (April 30, 2012), available at $\mathrm{http}: / /$ papers.ssm.com/sol3/papers.cfm?abstract_id $=2048810$.

${ }^{40}$ I.R.C. $\$ \$ 162(\mathrm{c})$, (e)-(g) (2011).

${ }^{41}$ I.R.C. $\$ 501(\mathrm{c})(3)$.

${ }^{42}$ I.R.C. $\$ 511-13$.

${ }^{43}$ HAZEN \& RATNER, supra note 25, at 14; cf., Roberta Romano, The Sarbanes-Oxley Act and the Making of Quack Corporate Governance (Nat'l Bureau for Econ. Research, Working Paper 04-032, 2004), available at http://papers.ssrn.com/sol3/papers.cfm?abstract_id=596101.

${ }_{44}$ Proxy Disclosure Enhancements, Sec. Act Rel. No. 33-9089, Sec. Exch. Act Rel. No. 34-61175, Inv. Co. Act Rel. No. IC-29092, 2009 WL 4857389 (SEC Dec. 16, 2009). For discussion, see Thomas L. Hazen, Diversity on Cor- 
The distinctive U.S. approach to business regulation suggests directions for integrating gender quotas with existing institutions. State corporate law is likely to be a weak vehicle for mandatory quotas because of interstate competition for corporate charters. A progressive state that enacts quotas may find that corporate charter "clients" migrate elsewhere.

By contrast, firms cannot avoid the federal tax law by moving from state to state; nor can they avoid federal securities laws if they intend to issue equity or debt into U.S. public markets. Tax and securities laws are highly salient to businesses, especially large businesses, which treat tax planning as a core corporate concern and who employ expert internal staffs (as well as external lawyers) to comply with tax and securities rules. Investors too are attuned to tax considerations and might well be interested in knowing whether companies are leaving tax dollars on the table or paying extra taxes.

To illustrate the possibilities, consider three options for the design of a U.S. program of gender quotas:

First, tax incentives and penalties could be useful primary or secondary legal vehicles for enacting quotas. The entire program could be enacted via the tax law through tax incentives for companies that comply -- indeed, the program could offer sliding subsidies that increase with increases in female representation (over some critical mass, say $30 \%$ ). Alternatively, tax subsidies and penalties might reinforce or magnify the effects of a mandate adopted by, say, the EEOC. Tax breaks could be offered as a reward for companies that meet their gender quota early on (before the expiration of a transition period) or that voluntarily comply even though outside the mandated group. Tax penalties might be added to conventional legal penalties for noncompliant companies once the transition period has passed.

Details are, of course, important to design. A standard tax credit would offer no financial benefit to nonprofits or forprofits with low or negative taxable income. By contrast, a refundable tax credit with refundability extended to nonprofits could provide the same financial incentive to all claimants. The magnitude of the credit matters too; further consideration

porate Boards -- Limits to the Business Rationale and the Connection Between Supporting Rationales and the Appropriate Response of the Law, 89 N.C. L. REV. 887 (2011). 
should be given to the merits of a small, symbolic initiative (perhaps combined with the publicity options discussed below) compared to a larger and more costly incentive program.

Second, securities laws could also be used as either the primary or secondary vehicle for quotas. As noted above, the SEC has already required firms to disclose board members' qualifications and to discuss whether board nominating committees consider diversity. ${ }^{45}$ This is, to be sure, a weak rule; it does not require firms to consider diversity or to defend homogeneous board appointments. Nor does it require the disclosure of the gender (or race) of existing board members. ${ }^{46} \mathrm{~A}$ stronger disclosure strategy might pose sharper questions: Are directors familiar with studies of gender bias in decisionmaking? Did the board take steps to cast a wide net for potential directors? How many women were interviewed for recent positions? How does the board intend to address diversity in the future? 47

Third, both tax and securities can assist in the publicity that may be important to the success of a gender quota. We should not be overly sanguine about the impact of disclosure on business practices; there is evidence illustrating that disclosure can become routine to both management and consumers rather than highly salient. ${ }^{48}$ Still, there are weaker and stronger forms of disclosure rules, and better design, combined with $\mathrm{NGO}$ and journalistic attention, can prompt disclosure of and attention to the right information. Tax law may seem an odd vehicle for disclosure because tax returns are traditionally private. But the law could easily require companies -- including private companies and nonprofits, neither of which file securities disclosures-to file a special, separate form disclosing the gender content of the boards of directors. That information could then be made available to the press and to advocacy or-

4517 C.F.R. 229.407(c)(2)(vi); see also Press Release, U.S. Securities and Exchange Commission, SEC Approves Enhanced Disclosure About Risk, Compensation and Corporate Governance (Dec. 19, 2009).

46 See Hazen, supra note 44 , at 43.

47 For a cautionary note and a summary of empirical findings on responses to diversity disclosure, see Aaron Dhir, Boardroom Diversity and Disclosure: A Nudge in the Right Direction? Commentary, THESTAR.COM (May 31, 2013), http://www.thestar.com/opinion/commentary/2013/05/31/board room_diversity_and_disclosure_a_nudge_in_the_right_direction.html.

${ }^{48}$ See Wong, supra note 39. 
ganizations. If tax incentives or penalties exist, the company might also be required to disclose whether the firm benefitted from any bonuses or suffered any penalties. In the case of penalties, a firm would be required to disclose why it was unable to meet diversity standards and how it planned to avoid the penalty the following year.

There are, of course, a large variety of design options for a U.S. quota program. My effort here is simply to point out that quotas need not mark a departure from U.S. business regulation but, instead, could fit readily into existing models.

\section{GENDER QUOTAS AND NONPROFIT ORGANIZATIONS}

Discussions of gender quotas typically target the corporate board, and most existing programs include public corporations or large corporations. But it is worth considering what kinds of organizations should be subject to a mandate or a voluntary effort. In the United States, the nonprofit sector merits particular attention because of its size and its thorough integration with business and government. That is, nonprofits in the United States occupy major sectors of the economy -- sectors that, in other countries, are the province of government.

Private philanthropy as a share of GDP is relatively high in the United States compared to Europe: the United States ranks third (at 4\% of GDP) among 36 developed and developing countries studied by Johns Hopkins researchers. ${ }^{49}$ The civil society workforce is also relatively large in the United States, representing $10 \%$ of the "economically active population." 50

The U.S. nonprofit sector encompasses many of the world's largest charities as well as major industries, notably education and health. Table 2 shows that, in addition to public charities, such as the Red Cross, the nonprofit sector includes private foundations such as the Gates Foundation and a variety of other organizations, including advocacy groups like the Sierra Club.

\footnotetext{
49 John Hopkins Center for Civil Society Studies, Comparative Data Tables, http://ccss.jhu.edu/publications-findings?did=308 (last updated Sept. 1, 2004).

50 Id. at Table 2.
} 
52 PACE INT'L L. REV. SYMPOSIUM ED. [Vol. 26::1

Table 2. Types of U.S. Nonprofits, $2010^{51}$

\begin{tabular}{|l|l|l|}
\hline Type & Examples & Number (\%) \\
\hline $\begin{array}{l}\text { Total tax-exempt or- } \\
\text { ganizations }\end{array}$ & Red Cross & $\begin{array}{l}1,565,497 \\
(62 \%)\end{array}$ \\
\hline Public charities & Gates Foundation & $\begin{array}{l}98,837 \\
(6 \%)\end{array}$ \\
\hline Private foundations & $\begin{array}{l}496,259 \\
(32 \%)\end{array}$ \\
\hline $\begin{array}{l}\text { Other types (e.g., } \\
\text { chambers of com- } \\
\text { merce, unions, politi- } \\
\text { cal lobbying organiza- } \\
\text { tions) }\end{array}$ & Sierra Club & \\
\hline
\end{tabular}

Surprisingly, the arts and religion represent vanishingly small portions of the U.S. nonprofit sector in dollar terms. As Table 3 illustrates, arts organizations earn just $2 \%$ of total nonprofit revenues, while religious organizations earn less than $1 \%$. Health care $(60 \%)$ and education $(16.4 \%)$ are the two largest types. Many hospitals are nonprofits, as are virtually every private college and private primary and secondary school in the United States.

51 Urban Institute, Quick Facts About Nonprofits, available at http://nces.urban.org/statistics/quickfacts.cfm. 
Table 3. Revenues of 501(c)(3) Organizations $s^{52}$

\begin{tabular}{|l|l|}
\hline Type & $\begin{array}{l}\text { Revenue in Billions (Percent- } \\
\text { age of Revenues) }\end{array}$ \\
\hline $\begin{array}{l}\text { Arts, culture, and hu- } \\
\text { manities }\end{array}$ & $\begin{array}{l}\$ 29.3 \text { billion } \\
(1.9 \%)\end{array}$ \\
\hline Education & $\begin{array}{l}\$ 248 \text { billion } \\
(16.4 \%)\end{array}$ \\
\hline Health & $\begin{array}{l}\$ 907.7 \text { billion } \\
(60 \%)\end{array}$ \\
\hline Human services & $\$ 196.4$ billion $(13 \%)$ \\
\hline Religion & $\$ 13$ billion $(0.9 \%)$ \\
\hline
\end{tabular}

Nonprofits also play a major role in the health care sector. Sixty percent of community hospitals are nonprofit, as are $50 \%$ of hospices and $30 \%$ of nursing homes. More than $60 \%$ of health insurance plans with more than 100,000 enrollees are nonprofit. ${ }^{53}$ And all major colleges and universities are nonprofits in the tax sense: they are either private nonprofits (Harvard and Yale, for instance) or state institutions (the University of Virginia or Indiana University, for example).

The size and scope of nonprofit enterprises in the United States begins to suggest the problem with gender quotas limited to for-profit corporate boards. Restricting gender quotas to the for-profit sector would require Exxon Mobil, for example (a large, U.S.-based public company) to comply with a gender quota while exempting other companies such as the United Way and the American Red Cross, two of the largest U.S. charities. ${ }^{54}$

\footnotetext{
52 Urban Institute, The Nonprofit Sector in Brief, 4 (2010), http://www.urban.org/UploadedPDF/412674-The-Nonprofit-Sector-in-Brief. pdf (Table 2).

53 Alliance for Advancing Nonprofit Health Care, The Value of Nonprofit Health Care, NONPROFITHEALTHCARE.ORG 1, http://www.nonprofit healthcare.org/resources/AllianceReport-ValueOfNonprofitHealthCare.pdf.

54 William P. Barrett, The Largest U.S. Charities for 2012, FoRBES (Nov.
} 
New York Presbyterian Hospital/Weill Cornell Medical Center is a nonprofit -- and the country's largest nonprofit hospital with 2,200 beds. ${ }^{55}$ Excluding nonprofits from quotas would thus excuse some of the nation's largest and most important businesses from gender equity in the boardroom.

Large corporate businesses are not unique in having severe underrepresentation of women in their top management and governing bodies. Women represent $16 \%$ of directors on boards of the Fortune 1000 and about $30 \%$ of members of governing boards of private and public universities. ${ }^{56}$ The Harvard Corporation (now 1/3 female) ${ }^{57}$ or the Yale Corporation (now $30 \%$ female) ${ }^{58}$ are typical. Thirty percent is surely better than sixteen, but both fall well short of gender parity. ${ }^{59}$ By contrast, when we look at all nonprofits, $48 \%$ of board members are female. ${ }^{60}$

Extending gender quotas to nonprofits would confer three benefits. First, a broad policy would extend the antidiscrimination benefits to a wider swath of female leaders and

8, 2012), http://www.forbes.com/top-charities/.

55 Kathleen Roney, Fifty Largest Non-Profit Hospitals in America, BECKERS HOSPITAL REV. (July 18, 2011), http:/www.beckershospitalreview. com/lists/50-largest-non-profit-hospitals-in-america.html.

56 See 2020 Women on Boards, 2020 Gender Diversity Index, http://www.2020wob.com/blog/2020-gender-diversity-index (for data on the Fortune 1000 companies). For data on universities, see Mirinda L. Martin, Governor's Choice: Gender Composition of Trustee Boards at Public Universities, CORNELL UNIV. (Oct. 1, 2010), available at http://digitalcommons.ilr.cornell edu/cgi/viewcontent.cgi?article=1146\&contex $\mathrm{t}=$ workingpapers (Figure 1, showing public and private universities).

57 Including President Drew Faust, four of the twelve members are women, based on their first names. President and Fellows (Harvard Corporation), HARVARD.EDU, http://www.harvard.edu/harvard-corporation (last visited Mar. $21,2014)$.

58 About: Leadership \& Organization, YALE.EDU, http://www.yale.edu/about/corporation.html (last visited Jan. 29, 2014) (excluding the ex officio members, the governor and lieutenant governor of Connecticut, five of the seventeen members of the Yale Corporation are women, based on their first names).

59 By contrast, in Fall 2012, 50\% of Yale College students were women; see Office of Institutional Research: Factsheet, YALE.EDU, http:/oir.yale.edu/yale-factsheet (showing that 2,677 of 5,379 undergraduates were women).

60 Nonprofit Governance Index, BOARDSOURCE 1, 27 (2010), http://www.boardsource.org/dl.asp?document_id=884 (based on a survey of 2,000 chief executives and board members of American nonprofits but not a statistically representative sample). 
to sectors of American business. Including universities in the quota system would convey the understanding that discrimination is a systemic problem, and not a pathology limited to corporations.

Second, and relatedly, a critical achievement of a successful gender quota policy will be the development of pathways to leadership for women. The importance of nonprofits in the health care and education sectors means that quotas could play a critical role in opening up avenues for female leadership in academia and in medicine.

Third, a broad policy of this type could also highlight the status of those nonprofits that already have substantial female representation. Offering favorable publicity to good actors would reward their achievement and show others that it is possible to find appropriate female board members.

There are, of course, policy and political tradeoffs. A broad policy potentially expands the class of opponents to quotas and expands the institutions that will worry (genuinely or as a pretext) that quotas will harm performance, forcing the hiring of unqualified directors.

\section{CONCLUSION}

To help gender quotas survive their transplant to the United States, we should be attentive to exceptional U.S. institutions. The federal tax code and securities law may be stronger candidates for implementation of a mandatory or voluntary effort than state corporate law. And the prominence of nonprofits in health care and education should prompt us to consider carefully whether some (or all) nonprofits should be subject to quotas as well.

To be sure, gender quotas face a host of design issues. The exemption of privately-held companies, for instance, should be a matter for concern, because many influential companies with large public presences are privately held. Forbes magazine reports that the top 220 private companies account for $\$ 1.4$ trillion in revenues and 4.2 million jobs. ${ }^{61}$ The list of 220 includes such household names as Fidelity Investments

61 Andrea Murphy \& Scott DeCarlo, America's Largest Private Companies 2012, FORBES (Nov. 28, 2012), http://www.forbes.com/largest-privatecompanies/. 
and Hallmark Cards. ${ }^{62}$

Careful design can assist in addressing pitfalls of gender quotas, including backlash and token appointments. For gender quotas to do more than create a few jobs for a few women, they should help create pathways for women to advance in leadership at all levels. The tax and securities law may be able to assist the process by, for instance, creating rewards and disclosure regimes for female leadership in management below the board level.

Sound design can also help address the worry that quotas will force firms to hire incompetent, untrained, or inexperienced female directors. These complaints may be pre-textual or uninformed in some cases, but in others they reflect genuine concern and knowledge about the relative scarcity of women in certain fields. Several solutions are possible, and a welldesigned regime of subsidies, penalties, and disclosure could amply accommodate them. For instance, a longer transition period may be desirable in certain industries where relatively few women have specialized expertise (e.g., engineering and computer science). Rather than a blanket exemption for certain industries, the law might require firms applying for an extended transition to disclose their reasons for failing to meet the quota and establish, say, a three- to five-year plan for identifying and grooming directors.

${ }^{62} I d$. 